\title{
Analisis Optimasi Pelaksanaan Proyek Revitalisasi Integrasi Jaringan Universitas Kadiri Menggunakan Metode PERT Dan CPM
}

\author{
Imam Safi' ${ }^{1}{ }^{*}$, Heribertus Budi Santoso ${ }^{2}$ \\ ${ }^{1,2)}$ Program Studi Teknik Industri, Universitas Kadiri \\ *Email: imam@unik-kediri.ac.id
}

\begin{abstract}
Abstrak
Proyek Revitalisasi Integrasi Jaringan Universitas Kadiri (INJANIK) merupakan proyek lanjutan dari tahun 2013 yang bergerak pada pengembangan sistem informasi. Dalam pelaksanaannya proyek mengalami hambatan atau penyimpangan sehingga menimbulkan ketidaktepatan waktu penyelesaian proyek. Dalam mengestimasi waktu dan biaya di sebuah proyek maka diperlukan optimalisasi. Penelitian ini bersifat menganalisis semua pekerjaan yang ada dalam proyek revitalisasi INJANIK dengan metode Program Evaluation and Review Technique (PERT) dan Critical Path Method (CPM). Pengumpulan data dilakukan secara langsung pada pelaksanaan proyek yang meliputi aktivitas kegiatan, jadwal serta anggaran biaya proyek. Dari hasil analisa menggunakan metode PERT dan CPM terhadap pelaksanaan proyek Revitalisasi Integrasi Jaringan Universitas Kadiri dapat disimpulkan bahwa durasi waktu optimal proyek adalah 142 hari dengan tingkat peluang keberhasilan proyek sebesar 85,54\% efisiensi yang didapat sebesar 3,4\% dan total biaya proyek optimal adalah sebesar Rp. 479.634.000 dengan efisiensi sebesar $1,22 \%$.
\end{abstract}

Kata Kunci: Manajemen Proyek, PERT, CPM

\section{Pendahuluan}

Proyek merupakan kegiatan yang rumit dan memiliki tahapan-tahapan kegiatan pekerjaan yang saling berhubungan satu dengan yang lain terbatasi oleh waktu, biaya dan kualitas. Pelaksanaan pekerjaan pada suatu proyek membutuhkan tidak hanya sumber daya manusia yang handal, tetapi juga suatu manajemen yang baik. Suatu proyek dapat dikatakan berhasil apabila mampu memenuhi tujuannya yaitu selesai pada waktu yang ditentukan, sesuai dengan biaya yang dialokasikan dan memenuhi kualitas yang disyaratkan. Demi kelancaran jalannya sebuah proyek dibutuhkan manajemen yang akan mengelola proyek dari awal hingga proyek berakhir, yakni manajemen proyek. Manajemen proyek mempunyai sifat istimewa, dimana waktu kerja manajemen dibatasi oleh jadwal yang telah ditentukan [4].

Proyek Revitalisasi Integrasi Jaringan Universitas Kadiri (INJANIK) merupakan proyek lanjutan dari tahun 2013 di Universitas Kadiri. Seiring berjalannya kemajuan bidang ICT dan tuntutan proses pengolahan data akademik Perguruan Tinggi yang menggunakan feeder PDDIKTI, maka tahun 2016 kebijakan dari lembaga Universitas Kadiri merasa perlu melakukan revitalisasi pembangunan jaringan data yang mencangkup 5 komponen didalamanya yaitu Internet, Server, Sistem Informasi, Website-Email, dan LAN-WAN guna mendukung proses pengolahan data akademik lebih efisien dan efektif. Aktivitas utama pada proyek ini yang meliputi kegiatan persiapan, kegiatan pengembangan, kegiatan implementasi dan kegiatan finishing. Proyek INJANIK merupakan proyek dalam jenis pelayanan manajemen yang dimana proyek ini mengembangkan dan merancang sistem informasi yang banyak berkenaan dengan non fisik dan berbeda karakternya dengan jenis proyek seperti manufaktur 
atau konstruksi. Dalam pelaksanaannya proyek mengalami hambatan atau penyimpangan sehingga menimbulkan ketidaktepatan waktu penyelesaian proyek. Menurut Cynthia dalam artikel yang ditulis oleh Aribisala, et.al. [1] mengatakan bahwa sebagian besar organisasi yang melakukan pengerjaan proyek tidak selesai tepat waktu dikarenakan pihak eksekutif tidak memiliki akses terhadap rencana dan jadwal proyek secara realtime. Tingkat ketepatan estimasi waktu penyelesaian proyek ditentukan oleh tingkat ketepatan perkiraan durasi setiap kegiatan di dalam proyek. Selain ketepatan perkiraan waktu, penegasan hubungan antar kegiatan suatu proyek juga diperlukan untuk perencanaan suatu proyek. Dalam mengestimasi waktu dan biaya di sebuah proyek maka diperlukan optimalisasi. Optimalisasi biasanya dilakukan untuk mengoptimalkan sumber daya yang ada serta meminimalkan risiko namun tetap mendapatkan hasil yang optimal [3].

Metode PERT (Program Evaluation and Review Technique) dan CPM (Critical Path Method) adalah metode yang dapat digunakan untuk membuat perencanaan, skedul, dan proses pengendalian suatu proyek. Untuk dapat menerapkan kedua metode ini, perlu ditetapkan terlebih dahulu kegiatankegiatan yang akan dilakukan dalam suatu proyek dan menyusunnya dalam bentuk jaringan. Jaringan menunjukan saling hubungan antara satu kegiatan dengan kegiatan lain. Walaupun prinsip penyusunan jaringan pada kedua metode adalah sama, namun terdapat perbedaan mendasar antara kedua metode ini. Perbedaan ini terletak pada konsep biaya yang dikandung CPM yang tidak ada di dalam metode PERT. Sedangkan pada PERT, penekanan diarahkan kepada usaha mendapatkan kurun waktu yang paling baik (ke arah yang lebih akurat).

Penelitian ini bersifat menganalisis semua pekerjaan yang ada dalam proyek revitalisasi INJANIK dengan metode PERT dan CPM. Analisis optimasi diartikan sebagai suatu proses penguraian durasi proyek untuk mendapatkan percepatan durasi yang paling baik (optimal) dengan menggunakan berbagai alternatif ditinjau dari segi biaya. Proses memperpendek waktu kegiatan dalam jaringan kerja untuk mengurangi waktu pada jalur kritis, sehingga waktu penyelesaian total dapat dikurangi disebut sebagai crashing proyek [5].

\section{Metode Penelitian}

Penelitian ini dimulai dengan studi literatur untuk mengetahui dasar dari penelitian, kemudian melakukan observasi dilapangan guna mengetahui kondisi dari obyek yang diteliti, sehingga didapatkan mengetahui permasalahan yang akan dibahas dan dijadikan tujuan pada penelitian ini. Batasan masalah serta asumsi ditentukan agar penelitian ini tidak keluar dari tujuan penelitian yang dilakukan.

Pengumpulan data dilakukan secara langsung pada pelaksanaan proyek revitalisasi jaringan Universitas Kadiri di Kediri yang meliputi aktivitas kegiatan, jadwal serta anggaran biaya proyek. Teknik analisis menggunakan pendekatan metode PERT dan CPM dengan tahapan tahapan sebagai berikut :

1. Memecah aktivitas utama proyek menjadi komponen- komponen kerja yang rinci untuk keperluan analisis jalur kritis. Menurut [7], tujuan memecah lingkup proyek menjadi komponen-komponennya antara lain untuk meningkatkan akurasi perkiraan kurun waktu penyelesaian proyek menyusun jaringan kerja (network planning).

2. Menggunakan langkah analisis PERT, Memasukkan waktu optimistis, waktu paling mungkin, dan waktu pesimistis pada tabel yang diperoleh dari data yang tersedia dilapangan serta pengalaman melakukan kegiatan proyek tersebut sehingga didapatkan waktu penyelesaian yang diharapkan serta nilai variannya dengan model analisis PERT [2].

3. Mencari jalur kritis dengan mengidentfikasi waktu mulai dan waktu selesai untuk setiap aktivitas kegiatan dengan menggunakan proses two-pass sehingga didapatkan nilai slack.

4. Selanjutnya menjumlahkan waktu yang diharapkan dan jumlah varians pada kegiatan jalur kritis yang sudah ditemukan untuk mencari nilai $\mathrm{Z}$ serta persentase peluang keberhasilan proyek dengan melihat kurva distribusi normal.

5. Mengidentifikasi crash time dan crash cost pada jalur kritis dengan metode percepatan durasi proyek (project crashing) dilakukan untuk mencari biaya proyek yang optimal dengan beberapa asumsi seperti jumlah sumber daya yang tersedia tidak merupakan kendala dan penambahan 
biaya pada kegiatan yang dipercepat bisa dengan menambah jumlah tenaga kerja, membeli peralatan, atau bentuk lain yang dinyatakan dalam sejumlah dana.

6. Menghitung biaya biaya langsung dan biaya tidak langsung dari perubahan akibat dilakukan project crashing sehingga didapatkan nantinya total biaya proyek

7. Tahap terakhir menghitung nilai efisiensi waktu dan biaya proyek

\section{Hasil dan Pembahasan}

Berikut pengumpulan data yang diperoleh dari kegiatan proyek Revitalisasi Integrasi Jaringan Di Universitas Kadiri seperti pada tabel 1.

Tabel 1. Daftar data kegiatan, biaya, serta kegiatan pendahulu

\begin{tabular}{clrcc}
\hline Kode & \multicolumn{1}{c}{ Kegiatan } & \multicolumn{1}{c}{$\begin{array}{c}\text { Biaya } \\
(\mathrm{Rp})\end{array}$} & $\begin{array}{c}\text { Waktu } \\
\text { (hari) }\end{array}$ & $\begin{array}{c}\text { Kode } \\
\text { pendahulu }\end{array}$ \\
\hline A & Survei Lokasi & 520.000 & 5 & \\
B & Identifikasi Kebutuhan Hardware & 780.000 & 7 & $\mathrm{~A}$ \\
C & Perencanaan Anggaran Kebutuhan & 1.680 .000 & 7 & $\mathrm{~B}$ \\
D & Pengembangan Proposal Proyek & 640.000 & 25 & $\mathrm{C}$ \\
E & Pemindahan Ruang Server & 600.000 & 4 & $\mathrm{D}$ \\
F & Pembelian Perangkat & 163.510 .000 & 6 & $\mathrm{D}$ \\
G & Migrasi Paket Server Hosting Website & 6.384 .000 & 10 & $\mathrm{D}$ \\
H & Penerapan Instalasi Jaringan & 7.200 .000 & 16 & $\mathrm{E}, \mathrm{F}$ \\
I & Konfigurasi HUB, APN dan Swicth & 800.000 & 3 & $\mathrm{H}$ \\
J & Migrasi Data & 4.500 .000 & 30 & $\mathrm{I}$ \\
K & Pembuatan SIAKAD & 100.900 .000 & 40 & $\mathrm{H}$ \\
L & Pembuatan Aplikasi Pendukung & 63.000 .000 & 17 & $\mathrm{~K}$ \\
M & Pemasangan Provider Internet & 1.760 .000 & 7 & $\mathrm{G}, \mathrm{H}$ \\
N & Penerapan Instalasi OS pada server & 6.000 .000 & 4 & $\mathrm{~K}, \mathrm{M}$ \\
O & Penerapan Instalasi OS pada PC & 600.000 & 3 & $\mathrm{~J}, \mathrm{~N}$ \\
P & Penerapan Hak Akses & 15.440 .000 & 16 & $\mathrm{O}$ \\
Q & Penerapan Koreksi Akhir & 15.440 .000 & 2 & $\mathrm{P}$ \\
R & Persetujuan Koreksi Akhir & 15.440 .000 & 4 & $\mathrm{Q}$ \\
S & Testing Sistem dan Jaringan & 24.000 .000 & 12 & $\mathrm{R}$ \\
\hline
\end{tabular}

Biaya pada tabel diatas merupakan biaya langsung, sedangkan biaya tidak langsung pada proyek Revitalisasi Integrasi Jaringan Di Universitas Kadiri terdiri dari biaya konsultan, pengawasan, dan administrasi sebesar Rp. 56.360.000,-. Jadi total biaya proyek keseluruhan adalah Rp. 485.554.000,dengan keseluruhan target waktu penyelesaian 147 hari.

Dari tabel 1 langkah selanjutnya menggunakan metode PERT dengan memberi waktu optimis $(a)$, waktu realistis $(m)$ dan waktu pesimistis $(b)$ sehingga didapatkan waktu yang diharapkan $\left(t_{e}\right)$ dengan rumus sebagai berikut:

$t_{e}=\frac{(a+4 m+b)}{6}$

Dan nilai variasi kegiatan $(v)$ dengan rumus sebagai berikut :

$v=\left(\frac{b-a}{6}\right)^{2}$ 
Hasil perhitungan terlihat seperti pada tabel 2.

Tabel 2. Daftar waktu optimis, waktu realistis, waktu optimis dan waktu yang diharapkan

\begin{tabular}{ccccccc}
\hline Kode & $\begin{array}{c}\text { Kode } \\
\text { pendahulu }\end{array}$ & $\begin{array}{c}\text { Waktu } \\
\text { optimis } \\
\text { (hari) }\end{array}$ & $\begin{array}{c}\text { Waktu } \\
\text { realistis } \\
\text { (hari) }\end{array}$ & $\begin{array}{c}\text { Waktu } \\
\text { pesimistis } \\
\text { (hari) }\end{array}$ & $\begin{array}{c}\text { Waku yang } \\
\text { diharapkan } \\
\text { (hari) }\end{array}$ & $\begin{array}{c}\text { Variasi } \\
\text { kegiatan }\end{array}$ \\
\hline A & & 4 & 5 & 7 & 5 & 0 \\
B & A & 5 & 7 & 8 & 7 & 0 \\
C & B & 4 & 7 & 10 & 7 & 1 \\
D & C & 14 & 25 & 30 & 24 & 7 \\
E & D & 2 & 4 & 7 & 4 & 1 \\
F & D & 5 & 6 & 8 & 6 & 0 \\
G & D & 7 & 10 & 15 & 10 & 2 \\
H & E, F & 10 & 16 & 20 & 16 & 3 \\
I & H & 2 & 3 & 6 & 3 & 0 \\
J & I & 30 & 30 & 31 & 30 & 6 \\
K & H & 15 & 40 & 41 & 36 & 9 \\
L & K & 15 & 17 & 20 & 17 & 6 \\
M & G, H & 4 & 7 & 9 & 7 & 1 \\
N & K M & 3 & 4 & 5 & 4 & 0 \\
O & J N & 2 & 3 & 4 & 3 & 0 \\
P & O & 13 & 16 & 19 & 16 & 1 \\
Q & P & 1 & 2 & 5 & 2 & 0 \\
R & Q & 2 & 4 & 6 & 4 & 0 \\
S & R & 10 & 12 & 15 & 12 & 1 \\
\hline
\end{tabular}

Dengan menggunakan konsep te, maka jalur kritis dapat diidentifikasi melalui proses two-pass terdiri atas forward pass dan backward pass untuk menentukan jadwal waktu untuk tiap kegiatan. ES (earlist start) dan EF (earlist finish) selama forward pass. LS (latest start) dan LF (latest finish) ditentukan selama backward pass. Pada jalur kritis berlaku slack $=0$ [7], nilai Slack didapat dengan rumus matematis sebagai berikut :

$$
\text { Slack }=\mathrm{LS}-\mathrm{ES} \text { atau Slack }=\mathrm{LF}-\mathrm{EF}
$$

Tabel 3. Hasil proses two-pass

\begin{tabular}{cccccccc}
\hline Kode & $\begin{array}{c}\text { Kode } \\
\text { pendahulu }\end{array}$ & $\begin{array}{c}\text { Early } \\
\text { start } \\
(\mathrm{ES})\end{array}$ & $\begin{array}{c}\text { Early } \\
\text { finish } \\
(\mathrm{EF})\end{array}$ & $\begin{array}{c}\text { Late } \\
\text { start } \\
(\mathrm{LS})\end{array}$ & $\begin{array}{c}\text { Late } \\
\text { finish } \\
(\mathrm{LF})\end{array}$ & Slack & $\begin{array}{c}\text { Jalur } \\
\text { kritis }\end{array}$ \\
\hline A & & 0 & 5 & 0 & 5 & 0 & Ya \\
B & $\mathrm{A}$ & 5 & 12 & 5 & 12 & 0 & Ya \\
C & $\mathrm{B}$ & 12 & 19 & 12 & 19 & 0 & Ya \\
D & $\mathrm{C}$ & 19 & 43 & 19 & 43 & 0 & Ya \\
E & $\mathrm{D}$ & 43 & 47 & 45 & 49 & 2 & Tidak \\
F & $\mathrm{D}$ & 43 & 49 & 43 & 49 & 0 & Ya \\
G & $\mathrm{D}$ & 43 & 53 & 84 & 94 & 41 & Tidak \\
H & $\mathrm{E}, \mathrm{F}$ & 49 & 65 & 49 & 65 & 0 & Ya \\
I & $\mathrm{H}$ & 65 & 68 & 71 & 75 & 6 & Tidak \\
J & $\mathrm{I}$ & 68 & 98 & 75 & 105 & 7 & Tidak \\
K & $\mathrm{H}$ & 65 & 101 & 65 & 101 & 0 & Ya \\
L & $\mathrm{K}$ & 101 & 118 & 125 & 142 & 24 & Tidak
\end{tabular}




\begin{tabular}{cccccccc} 
M & G, H & 65 & 72 & 94 & 101 & 29 & Tidak \\
N & K, M & 101 & 105 & 101 & 105 & 0 & Ya \\
O & J, N & 105 & 108 & 105 & 108 & 0 & Ya \\
P & O & 108 & 124 & 108 & 124 & 0 & Ya \\
Q & P & 124 & 126 & 124 & 126 & 0 & Ya \\
R & Q & 126 & 130 & 126 & 130 & 0 & Ya \\
S & R & 130 & 142 & 130 & 142 & 0 & Ya \\
\hline
\end{tabular}

Dari tabel 3 diketahui jalur kritis dari proyek ini adalah kegiatan A-B-C-D-F-H-K-N-O-P-Q-R-S. Waktu penyelesain proyek yang optimal dengan menjumlahkan waktu dari kegiatan pada jalur kritis yaitu 142 hari. Selanjutnya untuk mengetahui kemungkinan mencapai target jadwal dapat dilakukan dengan menghubungkan antara waktu yang diharapkan $\left(t_{e}\right)$ dengan target $T(d)$ yang dinyatakan dengan rumus :

$Z=\frac{T(d)-t e}{S}$

PERT menggunakan varians kegiatan jalur kritis untuk membantu menentukan varians proyek keseluruhan dengan menjumlahkan varians kegiatan kritis $\sum(v)$. Standar deviasi proyek $(S)$ dihitung dengan rumus :

$S=\sqrt{\text { Lvarian proyek jalur kritis }}$

Tabel 4. Hasil perhitungan varians kegiatan kritis, standar deviasi proyek, dan nilai kemungkinan mencapai target

\begin{tabular}{cccccc}
\hline Kegiatan & $\sum(v)$ & $S$ & $T(d)$ & $\left(t_{e}\right)$ & $Z$ \\
Jalur Kritis & & & & & \\
\hline A-B-C-D-F-H-K-N-O-P-Q-R-S & 22 & 4,7 & 147 & 142 & 1.066
\end{tabular}

Merujuk pada tabel distribusi normal dengan melihat nilai $Z$ sebesar 1,066 mendapat peluang 0.8554 , artinya ada peluang sebesar $85,54 \%$ untuk menyelesaikan proyek tersebut dalam kurun waktu 142 hari. Percepatan durasi waktu proyek dari target yang ditentukan (crashing project) yaitu dengan menambah biaya atau time cost trade off atau crash program. [7]. Dalam menganalisis proses crashing menggunakan metode CPM dengan asumsi berikut :

1. Jumlah sumber daya yang tersedia tidak merupakan kendala.

2. Penambahan biaya pada kegiatan yang dipercepat bisa dengan menambah jumlah tenaga kerja, membeli peralatan, atau bentuk lain yang dinyatakan dalam sejumlah dana.

Jenis kegiatan yang dipercepat dalam proyek ini adalah yang melalui jalur kritis yang waktunya relatif lama. Kegiatan yang dimaksud yaitu D yang dipercepat satu hari, dan kegiatan K yang dipercepat empat hari. Untuk kegiatan D adalah pengembangan proposal proyek awal sebelum dilakukan percepatan waktunya adalah 25 hari dan setelah dilakukan percepatan dengan biaya tambahan (slope) sebesar Rp. 80.000/hari. Sedangkan kegiatan K adalah pembuatan SIAKAD sebelum dilakukan 
percepatan waktunya adalah 40 hari dan dilakukan percepatan dengan tambahan biaya Rp. 1.000.000/hari dengan asumsi perhitungan dari pihak pengembang sistem.

Tabel 4. Hasil perhitungan crashing cost

\begin{tabular}{cccrrrrr}
\hline Kode & $\begin{array}{c}\text { Normal } \\
\text { time }\end{array}$ & $\begin{array}{c}\text { Crash } \\
\text { time }\end{array}$ & \multicolumn{1}{c}{ Normal Cost } & Crash Cost & (Slope) & $\begin{array}{c}\text { Crash } \\
\text { by }\end{array}$ & $\begin{array}{c}\text { Crashing } \\
\text { cost }\end{array}$ \\
\hline $\mathrm{A}$ & 5 & 5 & 520.000 & 520.000 & 0 & 0 & 0 \\
$\mathrm{~B}$ & 7 & 7 & 780.000 & 780.000 & 0 & 0 & 0 \\
$\mathrm{C}$ & 7 & 7 & 1.680 .000 & 1.680 .000 & 0 & 0 & 0 \\
$\mathrm{D}$ & 25 & 24 & 640.000 & 720.000 & 80.000 & 1 & 80.000 \\
$\mathrm{E}$ & 4 & 4 & 600.000 & 600.000 & 0 & 0 & 0 \\
$\mathrm{~F}$ & 6 & 6 & 163.510 .000 & 163.510 .000 & 0 & 0 & 0 \\
$\mathrm{G}$ & 10 & 10 & 6.384 .000 & 6.384 .000 & 0 & 0 & 0 \\
$\mathrm{H}$ & 16 & 16 & 7.200 .000 & 7.200 .000 & 0 & 0 & 0 \\
$\mathrm{I}$ & 3 & 3 & 800.000 & 800.000 & 0 & 0 & 0 \\
$\mathrm{~J}$ & 30 & 30 & 4.500 .000 & 4.500 .000 & 0 & 0 & 0 \\
$\mathrm{~K}$ & 40 & 36 & 100.900 .000 & 104.900 .000 & 1.000 .000 & 4 & 4.000 .000 \\
$\mathrm{~L}$ & 17 & 17 & 63.000 .000 & 63.000 .000 & 0 & 0 & 0 \\
$\mathrm{M}$ & 7 & 7 & 1.760 .000 & 1.760 .000 & 0 & 0 & 0 \\
$\mathrm{~N}$ & 4 & 4 & 6.000 .000 & 6.000 .000 & 0 & 0 & 0 \\
$\mathrm{O}$ & 3 & 3 & 600.000 & 600.000 & 0 & 0 & 0 \\
$\mathrm{P}$ & 16 & 16 & 15.440 .000 & 15.440 .000 & 0 & 0 & 0 \\
$\mathrm{Q}$ & 2 & 2 & 15.440 .000 & 15.440 .000 & 0 & 0 & 0 \\
$\mathrm{R}$ & 4 & 4 & 15.440 .000 & 15.440 .000 & 0 & 0 & 0 \\
$\mathrm{~S}$ & 12 & 12 & 24.000 .000 & 24.000 .000 & 0 & 0 & 0 \\
\cline { 5 - 6 } & & 429.194 .000 & 433.274 .000 & & & 4.080 .000 \\
\hline
\end{tabular}

Total biaya proyek adalah jumlah biaya langsung ditambah dengan jumlah biaya tidak langsung. Biaya langsung meningkat jika durasi dipercepat, sebaliknya Biaya tidak langsung menurun jika durasi dipercepat [7]. Biaya tidak langsung terdiri dari pengawasan, administrasi, konsultan yang didapat dari pihak pengelola proyek dimana penurunan total per hari adalah Rp. 2.000.000. Selanjutnya dari tabel 4 bisa dihitung total biaya seperti pada tabel 5 .

Tabel 5. Hasil perhitungan crashing cost

\begin{tabular}{ccrrr}
\hline $\begin{array}{c}\text { Waktu } \\
\text { proyek }\end{array}$ & $\begin{array}{c}\text { Biaya } \\
\text { kumulatif } \\
(\mathrm{Rp})\end{array}$ & $\begin{array}{c}\text { Biaya } \\
\text { langsung (Rp) }\end{array}$ & $\begin{array}{c}\text { Biaya tidak } \\
\text { langsung (Rp) }\end{array}$ & $\begin{array}{c}\text { Total biaya } \\
(\mathrm{Rp})\end{array}$ \\
\hline 147 & 0 & 429.194 .000 & 56.360 .000 & 485.554 .000 \\
146 & 80.000 & 429.194 .000 & 54.360 .000 & 483.634 .000 \\
145 & 1.080 .000 & 429.194 .000 & 52.360 .000 & 482.634 .000 \\
144 & 2.080 .000 & 429.194 .000 & 50.360 .000 & 481.634 .000 \\
143 & 3.080 .000 & 429.194 .000 & 48.360 .000 & 480.634 .000 \\
142 & 4.080 .000 & 429.194 .000 & 46.360 .000 & 479.634 .000 \\
\hline
\end{tabular}

Biaya kumulatif pada kurun waktu penyelesaian 147 hari adalah Rp. 0, dikarenakan tidak ada percepatan pada durasi kegiatan, setelah dilakukan crashing project diketahui bahwa total biaya pada jadwal waktu penyelesaian proyek selama 142 hari sebesar Rp. 479.634 .000 sehingga efisiensi waktu dan biaya proyek melalui metode PERT dan CPM dapat dihitung sebagai berikut: 
- Efisiensi Waktu Proyek

$$
\begin{aligned}
& 147-142=5 \text { hari } \\
& =\frac{5}{147} \times 100 \%=3,4 \%
\end{aligned}
$$

- Efisiensi Biaya Proyek

$$
\begin{aligned}
& \text { Rp. } 485.554 .000-\text { Rp. } 479.634 .000=\text { Rp. } 5.920 .000 \\
& =\frac{\text { Rp. } 5.920 .000}{\text { Rp. } 485.554 .000} \times 100 \%=1,22 \%
\end{aligned}
$$

Dari perhitungan diatas didapat efisiensi waktu sebesar 3,4\% sedangkan efisiensi biaya sebesar $1,22 \%$. Menurut Permana, 2016, walaupun rencana waktu proyek telah dibuat secara seksama dengan memperhitungkan segala faktor-faktor yang menjadi kendala, tetapi dalam pelaksanaannya kadangkala bisa tidak sesuai dengan apa yang telah direncanakan. Ketidaksesuaian yang terjadi itu dikarenakan adanya kendala-kendala yang timbul diluar dugaan.

\section{Kesimpulan}

Dari hasil analisa menggunakan metode PERT dan CPM terhadap pelaksanaan proyek Revitalisasi Integrasi Jaringan Universitas Kadiri dapat disimpulkan bahwa durasi waktu optimal proyek adalah 142 hari dengan tingkat peluang keberhasilan proyek sebesar 85,54\% efisiensi yang didapat sebesar 3,4\% dan total biaya proyek optimal adalah sebesar Rp. 479.634 .000 dengan efisiensi sebesar $1,22 \%$. Dalam pengerjaan proyek yang bergerak pada bidang pengembangan sistem informasi akan sangat berbeda dengan jenis proyek lain misal proyek konstruksi. Perbedaan tersebut terletak dari ruang lingkup proyek yang dimana dalam pengembangan sistem informasi ruang lingkup biasanya selalu akan mengalami perubahan, ini dikarenakan saat kegiatan testing ternyata sistem tidak sesuai harapan klien sehingga dilakukan penyempurnaan kembali. Ini akan berdampak pada penambahan durasi proyek sehingga perlu diprhatikan masalah mengenai ruang lingkup diawal proyek disetujui. Selanjutnya penelitian seperti ini bisa diperluas lagi dengan menggunakan metode percepatan durasi proyek yang lain semisal metode critical chain project.

\section{Daftar Referensi}

[1] Aribisala A, Otenaike A, Balogun O, Ofusori L. 2017. Analysis of an Engineering Project Using Program Evaluation and Review Technique. FUOYE Journal of Engineering and Technology, Volume 2. Department of Mechatronics Engineering, Federal University Oye-Ekiti, Ekiti State, Nigeria.

[2] Charles, Kirkpatrick.A. dan Levin, Richard,I. 1972. Perencanaan dan pengawasan dengan PERT dan CPM. Bhatara : Jakarta

[3] Dannyanti, Eka. 2010. Optimalisasi Pelaksanaan Proyek Dengan Metode PERT dan CPM. Undip

[4] Hartawan, Harry. n.d. Analisis Keterlibatan Manajemen Proyek dalamProses Perencanaan dan Pengendalian Proyek Selama Pelaksanaan Konstruksi. http://www.digilib.ui.ac.id/opac/themes/libri2/detail.jsp?id=80787. www.google.com. Diakses 9 Februari 2010

[5] Heizer, Jay dan Barry Render. 2005. Operations Management : Manajemen Operasi. Jakarta : Salemba Empat

[6] Nurhayati, 2010. Manajemen Proyek, Edisi Pertama. Graha Ilmu.

[7] Soeharto, Imam. 1999. Manajemen Proyek: Dari Konseptual Sampai Operasional, Erlangga, Jakarta. 